\title{
Influence of Chicken EggShell Powder Ratio with Coarse Rice Husk on Methyl Orange Removal from Aqueous Solution
}

Pengaruh Rasio Serbuk Kulit Telur Ayam dengan Sekam Padi Kasar pada Adsorpsi Metil Orange

\author{
Embun Rachma Haqiqi ${ }^{1 *}$, Dwi Ima Hikmawati ${ }^{2}$ \\ ${ }^{1,2)}$ Universitas PGRI Madiun, Department of Chemical Engineering \\ *email: embun.haqiqi@unipma.ac.id
}

Received: 16/05/19; Revised: 27/06/19; Accepted: 27/06/19

\begin{abstract}
Chicken eggshell and rice husk waste have been succesfully used as a potential adsorbent of methyl orange (MO). In this study, after the washing and drying process, chicken eggshells were mashed while the rice husk was left intact. Chicken eggshell powder and coarse rice husk were combined and varied its composition ratio by $3: 1,2: 1,1: 1,1: 2$, and $1: 3$. The adsorption process of $50 \mathrm{~mL}$ MO 20 ppm in aqueous solution with 11 grams of adsorbent was measured using the UV-Vis Spectrophotometer Genesys 20 at $465 \mathrm{~nm}$. Based on the results of the study, the adsorbent with a variation of 1: 1 in ratio was able to adsorb MO from the solution up to $27.70 \%$ within 60 minutes.
\end{abstract}

Keywords: Adsorbtion, chicken eggshell, low-cost adsorbent, methyl orange, rice husk.

\begin{abstract}
Abstrak
Limbah kulit telur ayam dan sekam padi telah berhasil dimanfaatkan potensinya sebagai adsorben larutan zat warna metil orange (MO). Pada penelitian ini, setelah proses pencucian dan pengeringan, kulit telur ayam dihaluskan sedangkan sekam padi dibiarkan utuh. Serbuk kulit telur ayam dan sekam padi kasar dikombinasikan dengan variasi rasio komposisi 3:1, 2:1, 1:1, 1:2, dan 1:3. Adapun proses adsorpsi $50 \mathrm{~mL}$ larutan $M O$ dengan konsentrasi 20 ppm dengan 11 gram adsorben diukur hasilnya dengan Spektrofotometer UV-Vis Genesys 20 pada panjang gelombang $465 \mathrm{~nm}$. Berdasarkan hasil penelitian, adsorben dengan variasi rasio 1:1 mampu mengadsorbsi MO dari larutan hingga 27,70\% dalam waktu 60 menit.
\end{abstract}

Kata kunci: adsorben ekonomis, adsorbsi, kulit telur ayam, metil orange, sekam padi.

\section{INTRODUCTION}

Methyl Orange (MO) with the formula $\mathrm{C}_{14} \mathrm{H}_{14} \mathrm{~N}_{3} \mathrm{NaO}_{3} \mathrm{~S}$ is a type of textile dyes that is often used in Indonesia. Methyl Orange is also used as an indicator for acid-base titration. Azoids and their derivatives are carcinogenic and are not easily degraded (Widjajanti, 2009). Thus, environmental pollution by textile dye waste disposed of into the water without proper processing is very dangerous.
Therefore, it is necessary to process waste through chemical, physical and biological processes. Among several methods, the dyes processing explored by many scientists is adsorption. This method is simple, low cost, and more efficient in its application (Karasetin et al., 2014; Yagub et al., 2014; Lafi \& Hafiane, 2016).

Indonesia is an agricultural country that generated biomass as source of adsorbent material that has been developed 
to address environmental pollution problems. It's reported that bagasse and sawdust have been used as an adsorbent for staining waste jeans (Sutiyani \& Sukarnen, 2015). Bagasse can be used as an adsorbent for cibacron red dyes (Diapati, 2009) and in wastewater, it can be used as an adsorbent for metal ions (Apriliani, 2010). Corn cob as an adsorbent for blue reactive dyes (Purnama \& Kurnianto, 2016) and as an adsorbent for an iron element in ground water (Rahayu \& Adhitiyawarman, 2014). Rice husks are the most abundant biomass generated by the rice milling industry as the main agriculture product in Indonesia. Rice husk has also been studied its potential as an adsorbent of heavy metal ions in water (Wardalia, 2016), Methyl red (Hassan \& Abdulhussein, 2015), methylene blue (Sharma et al., 2010), malachite green (Chowdhury et al., 2011) and as methyl orange adsorben (Mittal et al., 2007; Bamroongwongdee et al., 2018; Purbaningtias et al., 2015). Rice husk consists of cellulose, hemicellulose, lignin, silica, soluble, and moisture (Leiva et al., 2007; Ludueña et al., 2011).

Another material that is equally potent as adsorbent is chicken eggshell. Some applications of chicken eggshell as an adsorbent are to reduce the metal content of electroplating industrial wastewater (Susanto et al., 2017), improve the quality of used cooking oil (Fitriyana \& Safitri, 2015), the process of chromium separation (Daraei et al., 2013), and pergasol red adsorption by the batch process (Sanredina et al., 2017). Chicken eggshell's ability to adsorb textile dye from aqueous solutions has been studied by researchers (Salman et al., 2012). There are three types of adsorbent samples studied, they are chicken eggshells, chicken eggshells and membranes, and chicken eggshell's membranes, while textile dye samples used are methylene blue (cation), methyl orange (anion), and bromophenol blue (anion). Based on the results of the study, three forms of adsorbent have potential to reduce intensity of cationic and anionic dyes from water and liquid waste.

The methyl orange dye itself has been studied by several researchers. Methyl orange adsorption by utilizing chitosan (Mahatmanti \& Sumarni, 2003; Saha, 2010; Zhao et al., 2017), powdered pumpkin seed (Subbaiah \& Kim, 2016), zeolite (Widjajanti et al., 2011), kaolinite (Sejie \& Nadiye-Tabbiruka, 2016), bark powder (Egwuonwu, 2013), activated carbon (Chen et al., 2010), and eggshells (Nurlaili et al., 2017; Belay \& Hayelom, 2014) have been investigated for its activity under various conditions. However, the studied of MO removal using the combination of chicken eggshell and rice husk, in our knowledge, were not much reported in literature.

Literature studies have proven the potential of chicken eggshell and rice husk as adsorbents. The factors that support this potential are because of its ease of being found, its abundant existence, and its economy. The main factors that play a role in the adsorption process is the presence of functional groups of carbonate, amine, $-\mathrm{OH}$, and $-\mathrm{C}=\mathrm{O}$. Based on the results of the FTIR analysis, chicken eggshell samples showed carbonate mineral peaks and calcium carbonate vibrations omit in wave number regions 1417-1425.40; 875.68; and $711.73 \mathrm{~cm}^{-1}$ (Tsai et al., 2006; Carvalho et al., 2011; Zulfikar et al., 2013). As for the rice husk samples, -OH 
vibration peak appeared at $3448.72 \mathrm{~cm}^{-1}$ (Badriyah \& Putri, 2017), and $-\mathrm{C}=\mathrm{O}$ which could conjugate around 1649.19 $\mathrm{cm}^{-1}$ (Tarley \& Arruda, 2004). This result is not different from the previous research about both materials (Haqiqi, 2018 $8^{\mathrm{a}, \mathrm{b}}$ ). In the previous research, two powders materials were combined and varied the ratio to see their activity as an adsorbent (Haqiqi, 2018 ). Hence, in this research used coarse rice husk for comparison. Data collected by measuring the absorbance of methyl orange in aqueous solution both before and after the reaction with UV-Vis Spectrophotometer Genesys 20.

\section{MATERIALS AND METHODS Materials}

Chicken eggshell was obtained from Madiun's food stall and Ciherang rice husk was obtained from Bojonegoro. The other materials are Methyl orange (analytic), aquades (local), and tap water.

\section{Methods}

Chicken eggshells were separated from its membrane and washed with tap water. Then dried in the sun to dry and powdered by blending machine. After that, the chicken eggshell powder was heated at $105^{\circ} \mathrm{C}$ for 15 minutes. Meanwhile, rice husk was washed with tap water, then dried, and heated at a $105{ }^{\circ} \mathrm{C}$ for 15 minutes. Chicken eggshell powder and coarse rice husk were mixed together. The adsorbent was varied with the ratio of chicken eggshell powder and coarse rice husk as a) $3: 1$, b) $2: 1$, c) $1: 1$, d) $1: 2$, and e) $1: 3$.

About 11 grams of the adsorbent was put in a $100 \mathrm{~mL}$ glass bottle. Then 50 $\mathrm{mL}$ of $20 \mathrm{ppm}$ methyl orange in aqueous solution was added to the bottle.
Adsorption was carried out by the stirring process with a shaker at $200 \mathrm{rpm}$ for 60 minutes. After 60 minutes, bottles were taken from the shaker and allowed to stand still until the separation between the sediment and the solution appears. The solution was centrifuged for a better separation process. Furthermore, the absorbance value before and after the reaction was measured by a UV-Vis spectrophotometer Genesys 20.

\section{RESULTS AND DISCUSSION}

In this research, the adsorbent that was used is a combination of chicken eggshell powder with coarse rice husk. In order to find potential new types of adsorbents, these two economical, abundant, and easily found materials are combined. Previously there are researches that examined the character and adsorption capacity of combination adsorbents from chicken eggshell powder and rice husk (Haqiqi, 2018 ${ }^{\mathrm{a}, \mathrm{b}}$ ). As a new variable, in this study coarse rice husk was used. In a bottle containing 11 grams of the adsorbent with vary the ratio of material composition $3: 1$, 2: 1, 1: 1, 1:2, and 1:3, $50 \mathrm{~mL}$ of $20 \mathrm{ppm}$ methyl orange solution is added as shown in Figure 1.

Based on the results of observation, chicken eggshell powder without membrane has a brownish white color, grayish brown rice husk powder, and the dye solution has an orange color. Referring to the research procedure after being washed with tap water, the powder of chicken eggshell and coarse rice husk used only received a heating treatment at $105{ }^{\circ} \mathrm{C}$ for 15 minutes. As a preliminary study, the material was not washed with certain organic solvents and without any additives. This is intended to see the 
Influence of Chicken EggShell Powder Ratio with Coarse Rice Husk on Methyl Orange Removal from Aqueous Solution

activity at basic stage whether it is able to adsorb the methyl orange from aqueous solution.
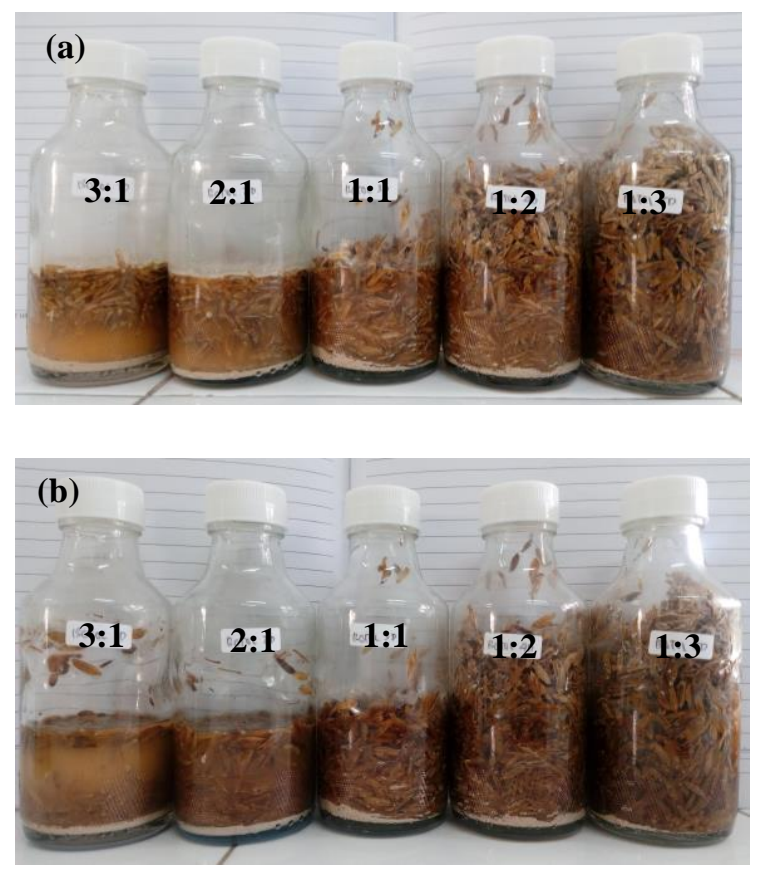

Figure 1. Adsorbent samples with variations in the ratio of chicken eggshells powder with coarse rice husks a) before adsorption, b) after adsorption.

Adsorption of methyl orange from aqueous solution lasts for 60 minutes at room temperature. The process was aided by stirring with the shaker at a speed of $200 \mathrm{rpm}$. The results showed the decreasing of MO absorbance. That means chicken eggshell powder combined with coarse rice husk succesfully used as an adsorbent for methyl orange removal.

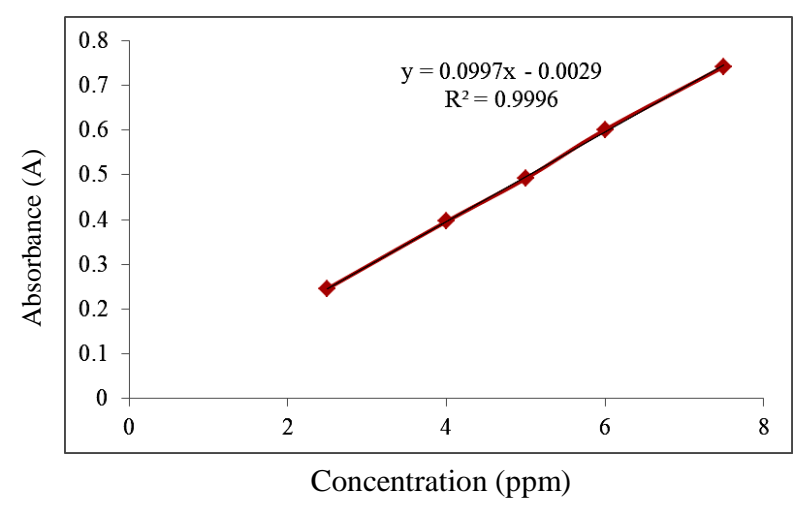

Figure 2. The calibration curve of MO
Based on the curves in Figure 3, the straight line equation is $\mathrm{y}=0.0097 \mathrm{x}-0.0029$. By using this equation, the final concentration of MO solution after adsorption could be found, as presented in Table 1. The \%removal of $\mathrm{MO}$ was calculated using equation 1 :

$$
\% \text { Removal MO }=\frac{C i-C f}{c i} \times 100 \% \ldots \text { eq. } 1
$$

Where $\mathrm{C}_{\mathrm{i}}$ is the initial MO concentration and $\mathrm{C}_{\mathrm{f}}$ is the final MO concentration.

Table 1. Adsorption data of adsorbent from chicken egg shell combined with coarse rice husk

\begin{tabular}{lccc}
\hline Sample & $\begin{array}{c}\mathbf{M}_{\text {before }} \\
\text { adsorption }\end{array}$ & $\begin{array}{l}\mathbf{M}_{\text {after }} \\
\text { adsorption }\end{array}$ & $\begin{array}{l}\boldsymbol{\%} \\
\text { Removal }\end{array}$ \\
\hline A (3:1) & $20 \mathrm{ppm}$ & $16.64 \mathrm{ppm}$ & $16.80 \%$ \\
B (2:1) & $20 \mathrm{ppm}$ & $14.74 \mathrm{ppm}$ & $25.80 \%$ \\
C (1:1) & $20 \mathrm{ppm}$ & $14.46 \mathrm{ppm}$ & $27.70 \%$ \\
D (1:2) & $20 \mathrm{ppm}$ & $14.96 \mathrm{ppm}$ & $25.20 \%$ \\
E (1:3) & $20 \mathrm{ppm}$ & $15.69 \mathrm{ppm}$ & $21.60 \%$ \\
\hline
\end{tabular}

Data from the measurement results of the absorbance using a UV-Vis spectrophotometer Genesys 20 in Table 1, shows that the highest decrease in absorbance was produced by the composite with a mass ratio of chicken eggshell powder with coarse rice husk 1: 1 is $27.70 \%$. The measurement data of 4 others samples with the mass ratio of chicken eggshell powder with coarse rice husk $3: 1$, 2: $1,1: 1,1: 2$, and $1: 3$ respectively are $16.80 \%$; $25.80 \%$; $25.20 \%$; and $21.60 \%$. This pattern is different from the methyl orange adsorption research using adsorbent combinations of chicken eggshell powder and rice husk powder. It's reported that the adsorbent combination of chicken eggshell powder and rice husk powder with the highest \%removal up to $55.90 \%$ was owned by a mass ratio of 1: 3 (Haqiqi, $\left.2018^{c}\right)$. Rice husks are seen to have the ability to absorb methyl orange which is 
more dominant than chicken eggshells in these conditions. Whereas, when was not using rice husk powder but coarse rice husk instead, the adsorption ability is different. This shows that the size of adsorbent affects the methyl orange adsorption. The decreases of material's size increases the surface area of adsorbent so removal efficiency increase.

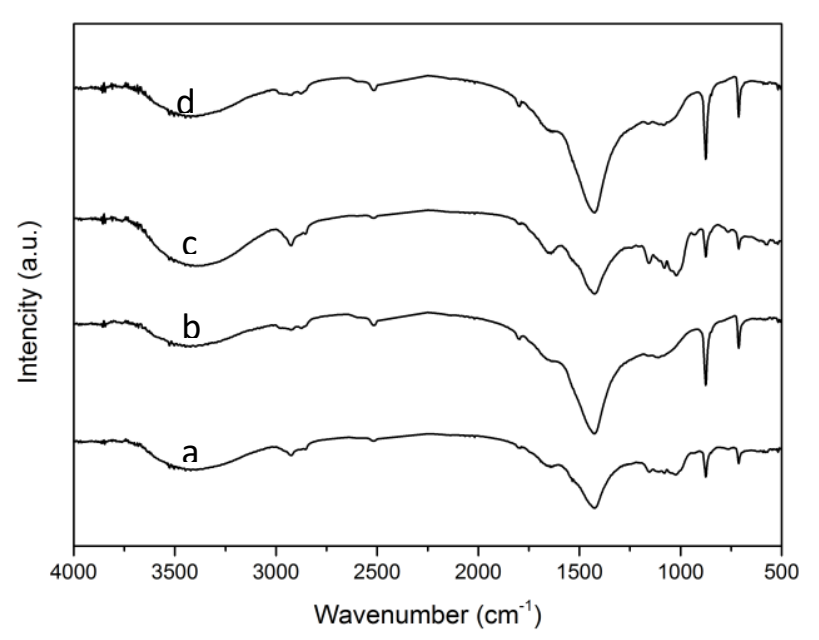

Figure 3. FTIR spectra of chicken eggshell powder with: a) rice husk powder, before adsorption, b) coarse rice husk, before adsorption, c) rice husk powder, after adsorption, d) coarse rice husk, after adsorption (Haqiqi, 2018 a).

Based on literature studies, which is shown in Figure 3, factors that play a role in the adsorption process include the presence of functional groups of carbonate, amine, $-\mathrm{OH}$, and $-\mathrm{C}=\mathrm{O}$. The results of FTIR analysis showed that the combination of chicken eggshell and rice husk had a functional group of carbonate minerals at wave number $1423.51-1425.44 \mathrm{~cm}^{-1}$, the peak of -OH strain at 3367.82-3431.48 $\mathrm{cm}^{-1}$, and at $1627.97-1647.26 \mathrm{~cm}^{-1}$ the peak of $-\mathrm{C}=\mathrm{O}$ appears (Haqiqi, 2018 ${ }^{\mathrm{a}}$ ). Differences of FTIR spectra before and after adsorption were on wavenumber shifting. Hydroxyl, amine and sulfonate groups on the surface of the adsorbent capable of reacting with dyes (Koumanova et al., 2002). The active side makes the adsorbent become positively charged so that it plays a large role in the electrostatic attraction of negative charged substances (Pramanpol \& Nitayapat, 2006).

\section{CONCLUSIONS}

Measurement data 5 composite samples (3:1, 2:1, 1:1, 1:2 and 1:3) with a UV-Vis spectrophotometer Genesys 20, respectively are $16.80 \% ; 25.80 \% ; 27.70 \%$; $25.20 \%$; and $21.60 \%$. Based on the results of these measurements, the chicken eggshell adsorbent combined with coarse rice husk and a variation of the ratio of 1: 1 were able to adsorb methyl orange from solution up to $27.70 \%$. Thus, the ratio of chicken eggshell and rice husk influence the adsorption capacity, especially their significant size difference between chicken eggshell and rice husk. Advice for the next research, when measure the absorbance, the blank used is not only aquades but using the adsorbent filtrate.

\section{ACKNOWLEDGMENT}

The author would like to thank LPPM UNIPMA and Education Department of Biology UNIPMA who have contributed to the completion of this article. LPPM UNIPMA has strongly supported the ongoing research through basic research grants for 2017-2018. The laboratory along with research tools and instruments have been prepared by the Education Department of Biology UNIPMA. Beside that, the author would like to thank United States Agency for International Development (USAID) for the training and mentoring support in writing this article, 

Aqueous Solution

through the Sustainable Higher Education Research Alliance (SHERA) Program for Universitas Indonesia's Scientific Modeling, Application, Research and Training for City-centered Innovation and Technology (SMART CITY) Project. Especially, Mr. Jaka Fajar F who has given great advice as a mentor. I do not forget to express my gratitude to colleagues in the Department of Chemical Engineering UNIPMA and other parties who have supported and played a role in this research.

\section{REFERENCES}

Apriliani, A. (2010). Pemanfaatan Arang Ampas Tebu sebagai Adsorben Ion Logam $\mathrm{Cd}, \mathrm{Cr}, \mathrm{Cu}$, dan Pb dalam Air Limbah. Skripsi. Fakultas Sainstek UIN Syarif Hidayatullah Jakarta.

Badriyah, L. \& Putri, M. P. (2017). Kinetika adsorpsi Cangkang Telur pada Zat Warna Metilen Biru. Journal of Chemistry, 5(3), 85-91.

Bamroongwongdee, C., Gaewkhem, S., \& Siritrakul, P. (2018). Kinetics, Equilibrium, and Thermodynamics of Methyl Orange Adsorption onto Modified Rice Husk. KMUTNB Int. J. Appl. Sci. Technol., 11(3), 185197.

Belay, K. \& Hayelom, A. (2014). Removal of Methyl Orange from Aqueous Solutions Using Thermally Treated Egg Shell (Locally Available and Low Cost Biosorbent). Chemistry and Materials Research, 6(7), 31-39.

Carvalho, J., Araujo, J., \& Castro, F. (2011). Alternative Low-cost Adsorbent for Water and Wastewater Decontamination Derived from Eggshell Waste: An overview. Waste Biomass Valor, 2, 157-167.
Chen, S., Zhang, J., Zhang, C., Yue, Q., Li, Y., \& Li, E. (2010). Equilibrum and kinetic studies of methyl orange and methyl violet adsorption on activated carbon derived from Phragmites australis. Desalination, 252, 149156.

Chowdhury, S., Mishra, R., Saha, P., \& Kushwaha, P. (2011). Adsorption thermodynamics, kinetics, and isosteric heat of adsorption of malachite green onto chemically modified rice husk. Desalination, 265(1-3), 159-168.

Daraei, H., Mittal, A., Noorisepehr, M., \& Mittal, J. (2013). Separation of chromium from water samples using eggshell powder as a low-cost sorbent: kinetic and thermodynamic studies. Desalination and Water Treatment. Hal. 1-7.

Diapati. M. (2009). Ampas Tebu Sebagai Adsorben Zat Warna Reaktif Cibacron Red. Skripsi. FMIPA, Kimia IPB.

Egwuonwu, P. D. I. M. (2013). Adsorption of Methyl Red and Methyl Orange Using Different Tree Bark Powder. Academic Research International, 4(1), 330-338.

Haqiqi, E. R. (2018). Analisis FTIR (Fourier Transform InfraRed) Adsorben Metil Orange dari Limbah Cangkang Telur Ayam Dikombinasi Biomassa Sekam Padi: Variasi Ukuran Sekam Padi. Proceeding Seminar Nasional SOEBARDJO BROTOHARDJONO XIV. ( ${ }^{\text {a) }}$

Haqiqi, E. R. (2018). Analisis FTIR (Fourier Transform Infrared) Adsorben Zat Warna dari Limbah Cangkang Telur Ayam Dikombinasi 
Biomassa Sekam Padi. Seminar Nasional Kimia, 17-25. ( ${ }^{\text {b) }}$

Haqiqi, E. R. (2018). Studi Awal Kemampuan Adsorpsi Komposit Kulit Telur Ayam dengan Sekam Padi sebagai Adsorben Metil Orange. Cheesa. 1(1), 15-20. (c)

Hassan, A. A. \& Abdulhussein, H. A. (2015). Methyl Red Dye Removal from Aqueous Solution by Adsorption on Rice Hulls. Journal of Babylon University, Engineering Sciences, 2(23), 1-12.

Fitriyana \& Safitri, E. (2015). Pemanfaatan Cangkang Telur Ayam Sebagai Adsorben Untuk Meningkatkan Kualitas Minyak Jelantah. Konversi. 4(1), 12-16.

Karaçetin, G., Sivrikaya, S., \& Imamoğlu, M. (2014). Adsorption of methylene blue from aqueous solutions by activated carbon prepared from hazelnut husk using zinc chloride. Journal of Analytical and Applied Pyrolysis, 110, 270-276.

Koumanova, B., Peeva, P., Allen, S. J., Gallagher, K. A., \& Healy, M. G. (2002). Biosorption from aqueous solution by egg shell membranes and Rhizopus oryzae: Equilibrium and kinetic studies. J. Chem. Technol. Biotechnol. 77, 539-545.

Lafi R. \& Hafiane, A. 2016. Removal of methyl orange (MO) from aqueous solution using cationic surfactans modified coffe waste (MCWs). Journal of the Taiwan Institute of Chemical Engineers, 58, 424-433.

Leiva, P., Ciannamea, E., Ruseckaite, R. A., \& Stefani, P. M. (2007). Medium-density particleboards from rice husks and soybean protein concentrate. Journal of Applied Polymer Science, 106(2), 1301-1306.

Ludueña, L., Fasce, D., Alvarez, V. A., \& Stefani, P. M. (2011). Nanocellulose from rice husk following alkaline treatment to remove silica. BioResources, 6(2), 1440-1453.

Mahatmanti, F. W. \& Sumarni, W. (2003). Kajian Termodinamika Penyerapan Zat Warna Indikator Metil Oranye (MO) Dalam Larutan Air Oleh Adsorben Kitosan. JSKA, VI(2), 119.

Mittal, A., Malviya, A., Kaur, D., Mittal, J., \& Kurup, L. (2007). Studies on the adsorption kinetics and isotherms for the removal and recovery of Methyl Orange from wastewaters using waste materials. 148, 229-240.

Nurlaili, T., Kurniasari, L., \& Ratnani, R. D. (2017). Pemanfaatan Limbah Cangkang Telur Ayam Sebagai Adsorben Zat Warna Methyl Orange Dalam Larutan. Inovasi Teknik Kimia, 2(2), 11-14.

Pramanpol, N., \& Nitayapat, N. (2006). Adsorption of reactive dye by eggshell and its membrane. Kasetsat J.: Nat. Sci. 40, 192-197.

Purbaningtias, T. E., Wiyantoko, B., Kurniawati, P., \& Ruwindya, Y. 2015. Removal of Methyl Orange in Aqueous Solution using Rice Husk. The $1^{\text {st }}$ International Seminar on Chemical Education 2015, 241-246.

Purnama, H. \& Kurnianto, A. R. (2016). Pemanfaatan Tongkol Jagung Untuk Adsorpsi Zat Warna Reactive Blue 19. The 3rdUniversty Research Coloquium. Hal. 41-47. 
Rahayu, A. N. \& Adhitiyawarman. (2014). Pemanfaatan Tongkol Jagung Sebagai Adsorben Besi Pada Air Tanah. JKK, 3(3), 7-13.

Saha, T. K. (2010). Adsorption of methyl orange onto chitosan from aqueous solution. Journal of Water Resource and Protection, 2(10), 898-906.

Salman, D. D., Ulaiwi, W. S., \& Tariq, N. M. (2012). Determination of the Optimal Conditions of Methylene Blue Adsorption by the Chicken Egg Shell Membrane. International Journal of Poultry Science. 11(6), 391-396.

Sanredina, Irianty, R. S., \& Yelida. (2017). Pengaruh Massa Adsorben terhadap Adsorpsi Pergasol Red dengan Proses Batch Menggunakan Cangkang Kulit Telur Terkalsinasi. Jom FTEKNIK, 4(1), 1-4.

Sejie, F. P. \& Nadiye-Tabbiruka, M. S. (2016). Removal of Methyl Orange (MO) from Water by adsorption onto Modified Local Clay (Kaolinite). Physical Chemistry. 6(2), 39-48.

Sharma, P., Kaur, R., Baskar, C., \& Chung, W. J. (2010) Removal of methylene blue from aqueous waste using rice husk and rice husk ash. Desalination, 259(1-3), 249-257.

Subbaiah, M. V. \& Kim, D-S. (2016). Adsorption of methyl orange from aqueous solution by aminated pumpkin seed powder: Kinetics, isotherms, and thermodynamic studies. Ecotoxicology and Environmental Safety. 128, 109-117.

Susanto, T. N., Atmono, \& Natalina. (2017). Pemanfaatan Limbah Cangkang Telur Ayam Sebagai Media Adsorben Dalam Penurunan Kadar Logam Kromium Heksavalen
(Cr6+) Pada Limbah Cair Industri Elektroplating. Ecolab, 11(1), 1-52.

Sutiyani, F. \& Sukarnen. (2015). Uji Efektivitas Pemanfaatan Limbah Ampas Tebu Dan Serbuk Kayu Sebagai Adsorben Untuk Pengolahan Air Limbah Pewarnaan Jeans. Seminar Nasional Sains dan Teknologi Terapan III. Hal. 663-670.

Tarley, C. R \& Arruda, M. A. (2004). Biosorption of heavy metals using rice milling by-products, Characterisation and application for removal of metals from aqueous effluents. Chemosphere. 54(7), 98795.

Tsai, W. T., Yang, J. M., Lai, C. W., Cheng, Y. H., Lin, C. C., \& Yeh, C. W. (2006). Characterization and adsorption properties of eggshells and eggshell membrane. Bioresource Technology, 97(3), 488-493.

Wardalia. (2016). Karakterisasi Pembuatan Adsorben Dari Sekam Padi Sebagai Pengadsorp Logam Timbal Pada Limbah Cair. Jurnal Integrasi Proses, 6(2), 83-88.

Widjajanti, E. (2009). Kajian Penggunaan Adsorben Sebagai Alternatif Pengolahan Limbah Zat Pewarna Tekstil. Proseding Seminar Nasional Kimia.

Widjajanti, E., Regina, T. P., \& Utomo, M. P. (2011). Pola Adsorpsi Zeolit Terhadap Pewarna Azo Metil Merah Dan Metil Jingga. Jurusan Pendidikan Kimia, FMIPA, Universitas Negeri Yogyakarta.

Yagub, M. T., Sen, T. K., Afroze, S., \& Ang, H. M. (2014). Dye and its removal from aqueous solution by adsorption: A review. Advances in 
Colloid and Interface Science, 209, 172-184.

Zhao, P., Zhang, R., \& Wang, J. (2017). Adsorption of methyl orange from aqueous solution using chitosan/diatomite composite. Water and Science Technology, In Press. Hal. 1-10.

Zulfikar, M. A., Novita, E., Hertadi, R., \& Djajanti, S. D. (2013). Removal of humid acid from peat water using untreated powdered eggshell as a low cost adsorbent. Int. J. Environ. Sci. Technol., 10, 1357-1366. 